\title{
Review
}

\section{Inotropes are not linked to Increased Mortality in Heart Failure}

\section{Maya Guglin*}

Division of Cardiovascular Medicine, Linda and Jack Gill Heart Institute, University of Kentucky, Lexington, KY

*Corresponding author: maya.guglin@uky.edu

\begin{abstract}
How to use inotropes is one of the most controversial topics in the management of heart failure. While most clinicians use these drugs, and recognize the state of inotrope dependency, current guidelines recommend them onlu as a bridge or palliation. Thus, inotropes are considered either neutral or detrimental in terms of outcomes. Meanwhile, properly designed randomized clinical trials testing the outcomes on inotropes, have never been performed and it is unlikely that they will ever be attempted. These trials would require randomizing patients with advanced heart failure, low output syndrome, and impaired end-organ perfusion into groups that received or not received inotropes, or received inotropes or placebo. Many physicians would consider this design unethical so the trials would be challenging to implement. But if it is unethical to deny inotropes to this subset of patients, we have to admit that inotropes do not only improve quality of life, but prolong it, or decrease mortality. Otherwise, we consider it unethical to deny the medication which increases mortality.
\end{abstract}

In this review, we analyze the current evidence relating to inotropes and outcomes. We demonstrate that the original trials were performed with agents that are no longer in use, or on patients without an indication for inotropes, or at a time before automatic cardio-defibrillators were recommended for primary prevention. We conclude that current guidelines for inotropes are misleading in their interpretation of outcomes in patients with advanced heart failure. The guidelines should be revised to adequately reflect the evidence.

\section{Keywords}

Inotropes; heart failure
Funding: Not applicable

Not Competing
applicable

interests:

Not

Citation: Guglin, M. (2015).
"Inotropes are not linked to increased mortality in heart http://dx.doi.org/10.13023/VAD.2

Editor-in-Chief: Maya Guglin,

Received: June 25, 2015

The Author(s). This is an the terms of the Creative (1.0 International (https://creativecommons.org/lice nses/by-nc/4.0/), which permits (estricted non-commercial use, any medium, provided that the original author(s) and the publication source are credited. 


\section{Introduction}

The role of inotropes in management of heart failure (HF) is changing. Mechanical circulatory support (MCS) offers increased survival and improved quality of life, far beyond the potential of inotropes. Nevertheless, many cardiologists still use them. It is much easier for the patient to accept continuous intravenous infusion of another drug, than to agree to an open heart surgery with implantation of hardware which requires serious maintenance and chronic anticoagulation. With rare exceptions, the left ventricular assist device (LVAD) implant is irreversible. Unlike medicine, it changes the lifestyle for a long time, till heart transplant, or forever. To the contrary, being on an inotrope is much less demanding. Because so many patients still remain on inotropes for months or even years, we want to clarify the issue of increased mortality, linked to the inotrope use.

At present, the use of inotropic agents in the management of HF is controversial. On one hand, specialists who manage patients with advanced HF utilize them widely. The Acute Heart Failure Global Survey of Standard Treatment (ALARM-HF) global survey of 666 hospitals in nine countries showed that inotropes were used in $39 \%$ of all admissions for acute HF ${ }^{1}$. In the Randomized Evaluation of Mechanical Assistance for the Treatment of Congestive Heart Failure (REMATCH) trial, $72 \%$ of patients in the medical arm and $65 \%$ of patients in the ventricular assist device arm were on inotropes 2 . Indeed, the HF community uniformly recognizes the state of "inotrope dependency". On the other hand, current guidelines caution that these drugs may be potentially detrimental: "Despite improving hemodynamic compromise, positive inotropic agents have not demonstrated improved outcomes in patients with HF in either the hospital or outpatient setting" 3 .

\section{Current Guidelines on Inotropes}

Guidelines of the American College of Cardiology Foundation/American Heart Association (ACCF/AHA) (2013) ${ }^{3}$, Heart Failure Society of America (2010) ${ }^{4}$, European Society of Cardiology (2012) ${ }^{5}$, and International Society for Heart and Lung Transplantation 6-8 have recommendations on inotropes in HF. The recommendations of various societies are summarized in Table 1. In general, inotropes are indicated in the presence of acute or chronic hemodynamic compromise with end organ dysfunction due to low output, and are considered to be detrimental and contraindicated if this syndrome is not present.

Specifically, the ACCF/AHA guidelines state that use of parenteral inotropic agents in hospitalized patients without documented severe systolic dysfunction, low blood pressure, or impaired perfusion, and evidence of significantly depressed cardiac output, with or without congestion, is potentially harmful ${ }^{3}$. 
These recommendations are based on profound understanding on pathophysiology of HF. As the disease progresses over time, the heart maintains normal cardiac output, but at the cost of rising left ventricular end diastolic pressure (Figure 1). The mainstay intervention at these stages is diuretic therapy, which decreases intracardiac filling pressures (congestion), along with medications favoring left ventricular reverse remodeling such as angiotensin converting enzyme inhibitors. Eventually, compensatory mechanisms fail, and cardiac output decreases. Only at this advanced stage, inotropes can be beneficial. Because low output is not present at the earlier stages, administration of inotropes cannot be favorable but can certainly cause harm because of side effects.

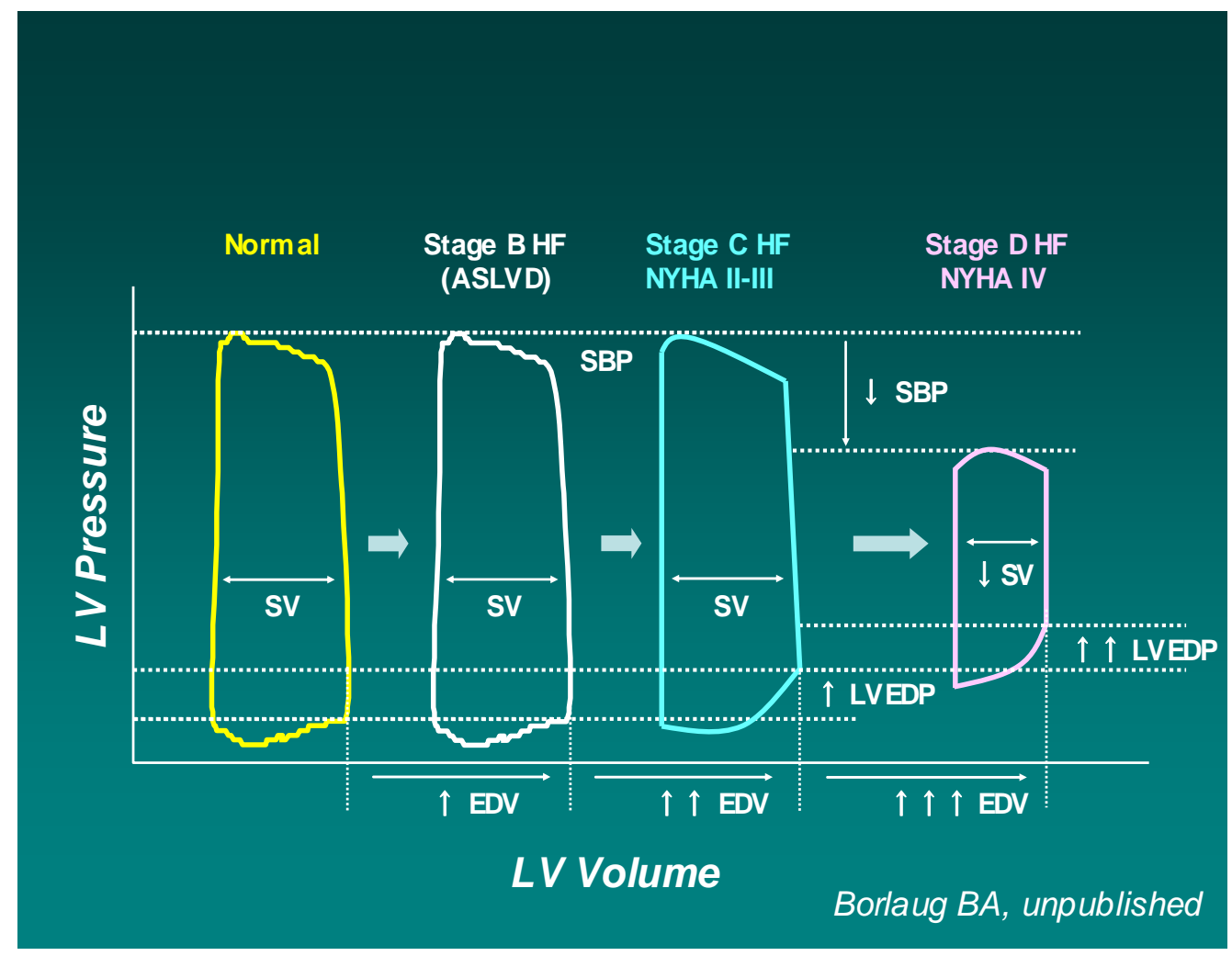

Figure 1. Hemodynamics in Heart Failure: a Progression (from Barry Borlaug, with permission)

\section{Inotropes: Hemodynamic Effects}

Milrinone and dobutamine are currently the only two inotropes approved for use in the United states and both exert their actions by increasing the intracellular level of cyclic adenosine monophosphate ${ }^{9}$. Dobutamine achieves this effect indirectly through adrenergic agonism while milrinone, a phosphodiesterase inhibitor, directly blocks cyclic monophosphate breakdown ${ }^{10}$. We reviewed the mechanism of action of both drugs in previously published paper ${ }^{11}$. 
Table 1. Guideline recommended indications for inotropic agents in heart failure

\begin{tabular}{|c|c|c|c|}
\hline Guidelines & & Strength & $\begin{array}{l}\text { Level of } \\
\text { Evidenc } \\
\text { e }\end{array}$ \\
\hline \multirow{6}{*}{$\begin{array}{l}\text { American College of } \\
\text { Cardiology } \\
\text { Foundation/American } \\
\text { Heart Association } \\
2013^{3}\end{array}$} & $\begin{array}{l}\text { Cardiogenic shock, until definitive therapy (e.g., coronary revascularization, MCS, } \\
\text { heart transplantation) or resolution of the acute precipitating problem }\end{array}$ & $\mathrm{I}$ & $\mathrm{C}$ \\
\hline & $\begin{array}{l}\text { "Bridge therapy" in stage D refractory to guideline determined medical therapy and } \\
\text { device therapy, while awaiting MCS or cardiac transplantation }\end{array}$ & IIA & $B$ \\
\hline & $\begin{array}{l}\text { Severe systolic dysfunction with low blood pressure and significantly depressed } \\
\text { cardiac output in hospitalized patients }\end{array}$ & IIB & $B$ \\
\hline & $\begin{array}{l}\text { Palliative therapy for symptom control in select patients with stage D despite optimal } \\
\text { guideline determined therapy, not eligible for either MCS or cardiac transplantation }\end{array}$ & IIB & $B$ \\
\hline & $\begin{array}{l}\text { Long-term IV inotropes, in the absence of specific indications or for reasons other } \\
\text { than palliative care, are potentially harmful }\end{array}$ & III & $B$ \\
\hline & $\begin{array}{l}\text { Inotropes in hospitalized patients without severe systolic dysfunction, low blood } \\
\text { pressure, or impaired perfusion, and evidence of significantly depressed cardiac } \\
\text { output, with or without congestion, is potentially harmful . }\end{array}$ & III & $B$ \\
\hline \multirow[t]{2}{*}{$\begin{array}{l}\text { European Society of } \\
\text { Cardiology } 2012^{5}\end{array}$} & $\begin{array}{l}\text { Inotropes should be considered in patients with hypotension (systolic blood pressure } \\
<85 \mathrm{mmHg} \text { ) and/or hypoperfusion }\end{array}$ & IIA & $\mathrm{C}$ \\
\hline & $\begin{array}{l}\text { Inotropes are NOT recommended unless there is hypotension (systolic blood } \\
\text { pressure }<85 \mathrm{mmHg} \text { ), hypoperfusion, or shock because of safety concerns (atrial } \\
\text { and ventricular arrhythmias, myocardial ischaemia, and death). }\end{array}$ & III & $\mathrm{C}$ \\
\hline \multirow[t]{3}{*}{$\begin{array}{l}\text { Heart Failure Society } \\
\text { of America } 2010^{4}\end{array}$} & $\begin{array}{l}\text { IV inotropes may be considered to relieve symptoms and improve end-organ } \\
\text { function in HF with LV dilation, reduced LVEF, and diminished peripheral perfusion } \\
\text { or end-organ dysfunction (low output syndrome), particularly if systolic blood } \\
\text { pressure is }<90 \mathrm{~mm} \mathrm{Hg} \text {, in symptomatic hypotension despite adequate filling } \\
\text { pressure, or unresponsiveness/intolerance of IV vasodilators. }\end{array}$ & $\begin{array}{l}\text { may be } \\
\text { consi- } \\
\text { dered }\end{array}$ & C \\
\hline & $\begin{array}{l}\text { Inotropes may be considered in similar patients with evidence of fluid overload if } \\
\text { they respond poorly to IV diuretics or have diminished/ worsening renal function. }\end{array}$ & $\begin{array}{l}\text { may be } \\
\text { consi- } \\
\text { dered }\end{array}$ & $\mathrm{C}$ \\
\hline & $\begin{array}{l}\text { IV inotropes are not recommended unless left heart filling pressures are elevated or } \\
\text { cardiac index is severely impaired }\end{array}$ & $\begin{array}{l}\text { not re- } \\
\text { commen- } \\
\text { ded }\end{array}$ & C \\
\hline \multirow[t]{2}{*}{$\begin{array}{l}\text { International Society } \\
\text { for Heart and Lung } \\
\text { Transplantation } 2006^{6}\end{array}$} & $\begin{array}{l}\text { In patients with decompensated HF and hypoperfusion in spite of adequate filling } \\
\text { pressures, inotropic or pressor therapy should be used. }\end{array}$ & $\mathrm{I}$ & $\mathrm{C}$ \\
\hline & $\begin{array}{l}\text { Long-term use of inotropic therapy should only be used as a pharmacologic bridge } \\
\text { to transplantation or for palliation. }\end{array}$ & 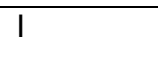 & $\mathrm{C}$ \\
\hline
\end{tabular}


The magnitude of hemodynamic effects of the inotropes on cardiac index and cardiac output is remarkable. Insurance carriers look for a $20 \%$ increase in cardiac index or a similar decrease in pulmonary wedge pressure, in order to issue an approval for continuous home inotropes ${ }^{12}$. However, greater response is common, with a twofold increase in cardiac index commonly observed ${ }^{13}$.

Milrinone in currently approved doses typically increases cardiac index by 24$42 \%$, decreases pulmonary capillary wedge pressure by $24-33 \%$, and reduces systemic vascular resistance by $15-31 \%$, with dose-dependent effect. The drug is effective in most patients, and those with the worst hemodynamic profile at baseline derived the most benefits ${ }^{12}$.

Most of hemodynamic effects of dobutamine and milrinone are similar ${ }^{14}$. Both dobutamine and milrinone

- Increase cardiac output

- Cause peripheral vasodilation

- Decrease pulmonary capillary wedge pressure

There are some differences between dobutamine and milrinone ${ }^{15-18}$

Dobutamine, in comparison with milrinone, causes

- Greater increase in heart rate

- Greater increase in myocardial oxygen consumption

- Greater proarrhythmic effect, including ventricular tachycardia 19,20

- Effects are attenuated in patients who receive beta blockers

Milrinone, in comparison with dobutamine, causes

- More hypotension

- Greater reduction in left and right heart filling pressures

- Greater reduction in mean arterial pressure

- Greater reduction in pulmonary arterial pressure

- Longer duration of action after discontinuation of the drip, especially in the presence of renal dysfunction

- Greater hemodynamic effects in general when the patient is on beta blockers

In direct comparison of dobutamine and milrinone, Colucci et al. ${ }^{17}$ found that milrinone caused a significantly greater reduction in left and right heart filling pressures and mean arterial pressure than did dobutamine, and for any given increase in $\mathrm{dP} / \mathrm{dt}$, milrinone caused a greater reduction in systemic vascular resistance than did dobutamine. Hemodynamic effects of dobutamine were blunted in patients with severe HF and elevated serum norepinephrine, most likely due to desensitization of myocardial beta 1 adrenoreceptors.

The biggest difference between the two especially in our expanding health care system may be cost. Dobutamine is cheaper ${ }^{21,22}$. For a course of in-hospital 
inotrope therapy, total acquisition cost of milrinone was significantly higher than that of dobutamine $(16,270$ dollars +/- 1334 versus 380 dollars +/- $533 \mathrm{P}$ $<.00001)^{21}$. In terms of arrhythmogenicity, dobutamine causes atrial and ventricular arrhythmias more commonly than milrinone, although both agents have proarrhythmic potential and hence both require continuous rhythm monitoring, at least while in the hospital. Milrinone causes nonsustained ventricular tachycardia in $3.7 \%$ of patients and sustained ventricular tachycardia in $0.5 \%{ }^{12}$.

Overall, hemodynamic properties of inotropes seem to be optimal for low output, or "cold" HF patients, especially if they are also "wet"23, i.e. have volume overload and increased intracardiac pressures. It is well known that this type of HF patients has the worst prognosis ${ }^{24}$. Besides, increase in cardiac output and decrease in congestion frequently results in improved urine output, a phenomenon widely known to HF doctors ${ }^{16,25}$.

It is quite counterintuitive that drugs with such remarkable hemodynamic effects can be detrimental in advanced HF.

Table 2. Properties of dobutamine and milrinone

\begin{tabular}{|l|l|l|l|}
\hline Inotrope & Dose & $\begin{array}{l}\text { Onset and } \\
\text { Duration of } \\
\text { action }\end{array}$ & Side effects \\
\hline Dobutamine & $\begin{array}{l}2.5 \text { to } 20 \\
\mu \mathrm{g} / \mathrm{kg} / \mathrm{min} \text { IV }\end{array}$ & $\begin{array}{l}\text { Onset of action } \\
\text { is 1 to } 10 \mathrm{~min}, \\
\text { peak effect } 10 \\
\text { to } 20 \text { min. The } \\
\text { half-life is } 2 \\
\text { min }\end{array}$ & $\begin{array}{l}\text { Ventricular ectopy, } \\
\text { tachycardia, } \\
\text { hypotension, angina, } \\
\text { palpitations, fever, } \\
\text { headache, nausea }\end{array}$ \\
\hline Milrinone & $\begin{array}{l}0.25 \text { to } 0.75 \\
\mu \mathrm{g} / \mathrm{kg} / \mathrm{min} \text { IV }\end{array}$ & $\begin{array}{l}\text { Onset of action } \\
\text { is } 5 \text { to } 15 \text { min. } \\
\text { The half-life is } \\
2.5 \text { hours }\end{array}$ & $\begin{array}{l}\text { Ventricular and } \\
\text { supraventricular } \\
\text { arrhythmias, angina, } \\
\text { hypotension, headache }\end{array}$ \\
\hline
\end{tabular}

\section{Inotrope Dependency}

The term "inotrope-dependent" is used liberally in the guidelines, without a formal definition. Patients are characterized as inotrope dependent if they cannot be weaned off inotropes at an experienced HF center ${ }^{4}$. Inotrope dependence means that withdrawal of inotropes leads to symptomatic hypotension, recurrent congestive symptoms, or worsening renal function ${ }^{26}$. It is recognized that 
symptoms and not purely the values of re-measured hemodynamic parameters have to be considered when deciding on inotrope dependence ${ }^{26}$.

The inotrope dependency is particularly important when determination of the need for advanced HF therapies such as heart transplantation or ventricular assist device. Profile one, or "crush and burn", includes patients who rapidly decline despite inotropes, profile two patients decline more gradually but still "Sliding on inotropes." Profile three includes most stable patients who still need to be on inotropes, with the description "stable blood pressure, organ function, nutrition, and symptoms on continuous intravenous inotropic support (or a temporary circulatory support device or both), but demonstrating repeated failure to wean from support due to recurrent symptomatic hypotension or renal dysfunction: "dependent stability." 27

The HFSA guidelines state that "these agents may help relieve symptoms due to poor perfusion and preserve end-organ function in patients with severe systolic dysfunction and dilated cardiomyopathy" ${ }^{4}$ End organ function in HF is usually related to hepatic and renal function. If inotropes help preserve liver and kidney function, they ought to prolong life, or to "avoid imminent death" 28 . The best definition of inotrope dependency we found in the paper by Hershberger et al. ${ }^{28}$ : "Inotropic dependence was defined as the failure to wean from inotropes because of imminent (minutes to hours) worsening of the patient's clinical status (combined objective [eg, blood pressure, level of consciousness, confusion, change in creatinine, oxygenation] and subjective [eg, dyspnea, confusion, weakness]), such that death appeared imminent, and the patient was deemed highly unlikely to survive inotrope withdrawal to permit hospital discharge". The authors state further that the attempted withdrawal of inotropic support in this cohort of patients can be acutely life-threatening ${ }^{28}$.

If we recognize that patients on inotropes cannot be weaned off of them, we have to admit that inotropes reduce mortality in this terminal end stage HF population. Otherwise, the term "inotrope dependent" becomes oxymoranical.

Inotrope dependency is the condition, which makes it unfeasible and ethically unacceptable to conduct any randomized controlled trials on inotropes versus placebo or inotrope versus no inotrope. The only comparison possible is one inotrope versus another, or inotropes versus a different mean of inotropic support, like in the REMATCH (Randomized Evaluation of Mechanical Assistance for the Treatment of Congestive Heart Failure) trial ${ }^{2}$. Indeed, Lynne Stevenson wrote in $2003{ }^{16}$ that randomized trials performed with and without inotropic infusions during HF hospitalizations have selected patients in whom intravenous therapy was not considered essential for management. Hershberger et al. also wrote that a randomized clinical trial designed to remove dobutamine from patients deemed inotrope-dependent would cause considerable discomfort from an ethical perspective ${ }^{28}$. Ten years later, this statement still holds true. But if you enroll only patients in whom the intervention is not essential, you cannot establish the value of the very intervention that is tested. 


\section{Patterns of Inotrope Use}

There are three distinct patterns of intravenous inotrope use: confined to hospital admission, intermittent home infusions (usually several times per week at the infusion center), and the infusions started in the hospital and continued at home continuously, weeks to months and even years in duration. In the past, some inotropes were also used orally in the outpatient setting. Below, we briefly summarize non-randomized studies based on the setting of infusion. The studies where patients were randomized into inotrope versus placebo or inotrope versus no inotrope, regardless of the setting where infusion was performed, are summarized in Tables 3-5 in the end of the manuscript. All studies, in the text and in the table, include patients with symptomatic HF and decreased left ventricular ejection fraction.

\section{Hospital Infusions}

- Some studies report the experience with in-hospital inotrope infusions when the patients were admitted not because of hemodynamic compromise and low output syndrome, but electively. A three-day dobutamine infusion in 29 patients resulted in hemodynamic and metabolic improvement, including elevation of sodium and improvement in renal function 29

- Intravenous milrinone given to 14 patients resulted in improved hemodynamics and allowed higher doses of diuretics and other HF medications. Oral angiotensin-converting enzyme inhibitor and diuretic doses were increased by $318 \%$ and $89 \%$, respectively. NYHA functional class improved from $3.8+/-0.4$ to $2.6+/-0.6$ following therapy, and there was a reduction in hospital admissions in 10 patients who responded to therapy during the subsequent year compared with the year before treatment $(4+/$ 17 versus $17+/-15)^{30}$.

- Intermittent infusions of either dobutamine patients) or nitroprusside was given to a total of 113 patients for about a month. There was a higher re-hospitalization rate $(86 \%$ versus $57 \%, p<0.02)$ and higher mortality $(58 \%$ versus $28 \%)$ in the dobutamine group. The decision of using dobutamine versus nitroprusside was made by individual physicians. Baseline systolic blood pressure was $90 \mathrm{mmHg}$ in the dobutamine group and 95 $\mathrm{mmHg}$ in the nitroprusside group; there is no indication whether this difference was significant. Heart transplantation was done in $78 \%$ of those on dobutamine and only in $48 \%$ of those on nitroprusside ${ }^{31}$. 
- In 261 patients, in-hospital infusion of nesiritide in two different doses was compared with dobutamine. Six-month mortality was lower in the nesiritide groups ${ }^{32}$.

This last study was designed to compare the outcomes in patients with infusion of nesiritide in a lower and higher dose versus any other vasoactive drug, at the discretion of the investigator, and patients were randomized into these three arms. Some patients in the arm with vasoactive drug were on dobutamine. The comparison between nesiritide and dobutamine was therefore a comparison between non-randomized groups, with very limited number of baseline characteristics and no invasive hemodynamic information. Moreover, mean baseline systolic blood pressure was $120 \mathrm{mmHg}$, and blood pressure below 90 $\mathrm{mmHg}$ was an exclusion criterion. Consequently, the study omitted all patients with low output HF syndrome, fundamentally excluding the only patients with an indication for dobutamine use. This essential design flaw makes the study inconclusive. The study of Capomolla et al. ${ }^{31}$ is also inconclusive due to lack of randomization.

Comparison of dobutamine versus milrinone in hospitalized patients, awaiting heart transplantation, did not show a clear advantage of one or the other in terms of right heart hemodynamics, death, need for additional vasodilator/inotropic therapy, need for mechanical cardiac support before transplantation, or ventricular arrhythmias requiring increased antiarrhythmic therapy ${ }^{21}$.

\section{Intermittent home infusions}

Historically, intermittent infusions of inotropes were used as a treatment for end stage HF with severe symptoms (NYHA III/IV). This practice is no longer supported and is a Class III recommendation per $\mathrm{ACC}^{\mathrm{A}} \mathrm{AHA}^{3}$. We summarized the outcomes in our previous article ${ }^{11}$. Randomized controlled trials are included into Tables 3-5.

\section{Continuous home infusions}

Continuous inotrope infusion at home is more relevant to today's practice than intermittent treatments. Such infusion may be used to improve symptoms and to better quality of life in hospice patients, in addition to acting as a bridge to cardiac transplant in candidates awaiting a donor. A decrease in the need for HF hospitalizations after initiation of continuous home inotrope infusions was suggested by the analysis of the Medicare data ${ }^{33}$.

- $\quad$ Continuous home infusion of dobutamine or milrinone in 24 and 7 patients, respectively, resulted in improvement in NYHA functional class from $4.0+/-0.0$ to $2.7+/-0.9(p<0.0001)$, decrease of number of hospital admissions and length of stay from $20.9+/-12.7$ to $5.5+/-5.4$ days $(p=0.0004)$, as well as a $16 \%$ reduction in cost of care in comparison to control period preceding the therapy ${ }^{34}$. 
- Continuous home infusion of milrinone was used in 60 heart transplant candidates and resulted in hemodynamic and symptomatic improvement as well as cost reduction, with $88.3 \%$ of patients eventually undergoing heart transplant ${ }^{35}$.

- Continuous home infusion of milrinone was given to 29 heart transplant candidates and resulted in hemodynamic and symptomatic improvement 36

- Continuous home infusion of milrinone (8 patients) or dobutamine (12 patients) given as a bridge to cardiac transplantation, resulted in improvement of functional status, serum creatinine, better hemodynamic parameters, and decreased number of hospitalizations during positive inotropic infusion therapy when compared with pre-treatment baseline ${ }^{37}$

- Continuous home infusion of dobutamine (4 patients), dopamine (13 patients), or the combination of both (6 patients) resulted in reduction of the number of days spent in the hospital ${ }^{38}$

- Continuous (4 patients) and intermittent (7 patients) home infusion of dobutamine in 11 patients resulted in symptomatic improvement 39

The number of reported deaths while on inotropes varied greatly among the studies, but since there were no control groups, and same patients' historical data were used as control, no conclusion about mortality can be derived.

\section{Mortality Data and Randomized Studies}

There is a relative paucity of randomized control studies on the mortality effect of inotropes in HF. Thus, to date, much of the data on the subject has been drawn from retrospective analysis. Overall, the data suggests that mortality of patients treated with intravenous inotropes is high. In the Evaluation Study of Congestive Heart Failure and Pulmonary Artery Catheterization Effectiveness (ESCAPE) trial, six month mortality in patients with HF receiving inotropes during hospitalization reached $19 \%{ }^{40}$, while the analysis of the Medicare data indicated that in patients treated with continuous home inotrope infusion, a six month mortality exceeded $40 \%{ }^{33}$. Analysis of the Acute Decompensated Heart Failure National Registry (ADHERE), showed that inotropic treatment with dobutamine and milrinone was associated with a $200 \%$ increase of in-hospital mortality in comparison to vasodilators ${ }^{41}$. However, baseline characteristics of the patients on inotropes, such as systolic blood pressure over $120 \mathrm{mmHg}$, demonstrate that they did not have low output syndrome. Only $8 \%$ of patients, started on inotropes, had systolic blood pressure less than $90 \mathrm{mmHg}$. 
Moreover, the Flolan International Randomized Survival Trial (FIRST), determined that six month mortality among patients on dobutamine was $70 \%$, with dobutamine being the strongest independent predictor of mortality in the study ${ }^{42}$. Use of dobutamine or milrinone was consistent with very poor prognosis, even in comparison with other intravenous vasoactive drugs like vasodilators ${ }^{41}$. The addition of more than one inotrope is associated with further mortality increase ${ }^{43}$. High mortality rate alone, however, does not in itself prove that inotropes are detrimental. Indeed, mortality is expected to be high by virtue of the advanced disease states in those who require inotropes.

Meta-analyses and retrospective analyses examining the mortality effect of inotropes in HF have been largely mixed. A meta- analysis of multiple placebo-controlled trials by Thakray et al. ${ }^{44}$ failed to demonstrate increased mortality on inotropes, while another meta-analysis on phosphodiestherase-3 inhibitors showed poorer outcomes on these agents ${ }^{45}$. In another retrospective study, no mortality difference was found between dobutamine and milrinone at home in a single center experience ${ }^{46}$, although milrinone was deemed more effective as a bridge to transplant, allowing more patients to be bridged by inotropes alone, without the need for mechanical circulatory support. Also, renal and hepatic function improved on milrinone ${ }^{47}$.

Some suggestions of increased mortality on inotropes come from post-hoc analyses of trials not designed to test the outcomes on inotropes where no randomization on inotrope versus no inotrope or placebo was conducted. For example, the FIRST trial was a randomized, controlled trial, designed to test the effects of continuous intravenous epoprostenol plus conventional therapy versus conventional therapy alone in patients with advanced HF. Some patients who entered the trial were also on intravenous dobutamine ${ }^{42}$. The analysis of the outcomes depending on the use of dobutamine is therefore flawed because the patients who required inotropes were sicker ( $89 \%$ in NYHA IV) than those who did not $(53 \%)$.

We grouped the randomized trials on inotropes into three categories: trials that demonstrate negative effects of inotropes on clinical outcomes, those that show neutral effects, and those that show beneficial effects of inotropes (Table 3).

Increased mortality was found on oral enoximone ${ }^{48,49}$, oral vesnarinone 50 , oral ibopamine ${ }^{51}$, oral milrinone ${ }^{51,52}$, and beta agonist xamoterol. Vesnarinone was associated with a dose-dependent increase in mortality mostly due to arrhythmic death ${ }^{50}$. None of these inotropes is currently in use, for the very reason of being associated with high mortality, and hence none of these outcomes are pertinent to the effects of intravenous dobutamine or milrinone. Besides, inotropes are proarrhythmic, and sudden cardiac death is considered the main mechanism responsible for excess mortality on inotropes ${ }^{50}$. Meanwhile, all the above studies were conducted before the time when implantation of automatic cardioverters-defibrillators had become the routine. Today, many of 
the patients on inotropes are implanted with defibrillators by the time they are inotrope dependent, and they are largely protected from arrhythmic death.

Indirectly, this consideration is confirmed by the study of Drakos et al. Due to concern that arrhythmia might contribute to inotrope-induced mortality, they compared end stage HF patients on intermittent inotropes versus conventional medical management, adding oral amiodarone to both groups (inotropes were represented by either dobutamine or levosimendan). The study was not randomized. The 6 -month (51\% versus $18 \%)$ and 1 -year $(36 \%$ versus $9 \%$ ) survival rates were significantly higher ( $p=0.001$ for both), and functional status was better, in patients on inotropes and amiodarone ${ }^{53}$. Earlier, the same group of authors demonstrated similar results in a randomized placebo controlled study (see Tables 3-5) ${ }^{54}$.

The majority of randomized studies are neutral demonstrating neither benefit nor detriment of inotropes. In the Outcomes of a Prospective Trial of Intravenous Milrinone for Exacerbations (OPTIME-CHF) trial of 951 patients admitted for acute decompensated HF, there were no significant differences of in hospital mortality, 60 day mortality or combined 60 day death when comparing milrinone versus placebo ${ }^{55}$. Post hoc subgroup analysis did reveal an increase in a composite of death or re-hospitalization in patients with coronary artery disease treated with milrinone versus placebo ( $42 \%$ versus $36 \%$ ), although no difference was found between the two groups in non-ischemic patients ${ }^{56}$. The ESSENTIAL trial examined the effect of low dose enoximone on patients with advanced HF on optimal medical therapy, and also showed no mortality difference 57 . In another study, oral enoximone used for weaning from intravenous inotropes, did not affect the mortality ${ }^{58}$. Other authors ${ }^{59-65}$ also reported no difference in terms of mortality between inotropes and placebo.

Conversely, relatively few studies demonstrated beneficial effects of inotropes on mortality. Similarly to those trials showing increased mortality, most studied agents are not currently in use and therefore not very pertinent: enoximone ${ }^{58,66}$, vesnarinone ${ }^{67}$, amrinone ${ }^{68}$. The only study on dobutamine in this group used it in combination with amiodarone to negate potential proarrhythmic effects. Mortality reduction on dobutamine plus amiodarone versus placebo plus amiodarone had hazard ratio of 0.403 (95\% confidence intervals $0.164-0.992 ; p=0.048)$.

But the main observation from reading reports of inotrope use, randomized or not randomized, is that very few authors report the data on central hemodynamics. We saw in multiple sets of guidelines cited in the beginning of this review that the only indication for inotropes in HF is low output syndrome. Meanwhile, very few papers provide hemodynamic data. It means, that in most studies, cardiac index/cardiac output were not even measured, and patients were enrolled based on symptomatic HF and decreased left ventricular ejection fraction, which is not an equivalent for low output syndrome. Moreover, in the OPTIME-CHF trial, patients were excluded if their doctors thought that inotropes were indicated ${ }^{55}$. Therefore, the effects of inotropes were tested on patients 
who did not have indications for them, which is the best way to evaluate for side effects without therapeutic benefits. following features:

In summary, most randomized controlled trials with inotropes share

- They were performed with pharmacologic agents that are currently not in use. The reason for them being no longer used is the fact that they increase mortality. This does not mean, however, that the effects of the drugs, which proved to be detrimental, can be extrapolated to currently used agents.

- They were performed in the years when automatic cardiovertersdefibrillators were not recommended for primary prevention, and an excess of sudden death may not be pertinent to current situation when the patients with advanced cardiomyopathy are protected with implanted defibrillators.

- They were performed on patients who did not have any evidence of low output syndrome and therefore did not have indications for inotropes.

\section{Conclusions}

Randomized controlled trials with inotropes share certain common features: they were performed with inotropes that are not currently in use; they were performed before the time when automated cardioverter-defibrilators became standard of care for primary prevention of sudden cardiac death; and they were performed on patients without evidence of low output heart failure and without indications for inotropes. Thus, these studies may not be generalizable to our current clinical practice.

Currently, there is no evidence to suggest that in patients with low output syndrome, treated according to the current guidelines, and protected by implantable cardioverters-defibrillators, inotropes increase mortality. To the contrary, recognition of the state of inotrope dependency is incompatible with the statement that inotropes increase mortality. 
Table 3. Randomized control trials of inotropes in heart failure: poor outcomes of inotropes

\begin{tabular}{|c|c|c|c|c|c|c|}
\hline Source, design & $\mathrm{N}$ & Follow-up & Inotrope & $\begin{array}{l}\text { Cardiac } \\
\text { index at } \\
\text { baseline }\end{array}$ & Mortality & $\begin{array}{l}\text { Other Outcomes in the } \\
\text { Inotrope group versus } \\
\text { Placebo }\end{array}$ \\
\hline $\begin{array}{l}\text { Cohn et al, } 1998^{53} \\
\text { Vesnarinone Trial, } \\
\text { randomized to } \\
\text { vesnarinone in two } \\
\text { different doses and } \\
\text { placebo }\end{array}$ & 3833 & 286 days & $\begin{array}{l}\text { Vesnarinone, } \\
\text { oral }\end{array}$ & $\begin{array}{l}\text { Not } \\
\text { reported }\end{array}$ & $\begin{array}{l}\text { Mortality: } \\
\text { Vesnarinone lower dose: } \\
21 \% \\
\text { Vesnarinone higher } \\
\text { dose: } 22.9 \% \\
\text { Placebo: } 18.9 \%, \text { p<0.02 } \\
\text { (versus placebo), the } \\
\text { difference is presumably } \\
\text { due to sudden } \\
\text { (arrhythmic) death. }\end{array}$ & Improved quality of life \\
\hline $\begin{array}{l}\text { Cowley et al., } 1994^{52} \\
\text { The Enoximone trial } \\
\text { A randomized, double } \\
\text { blind, placebo controlled } \\
\text { trial: Enoximone vs } \\
\text { placebo }\end{array}$ & 151 & One year & $\begin{array}{l}\text { Enoximone, } \\
\text { oral }\end{array}$ & $\begin{array}{l}\text { Not } \\
\text { reported }\end{array}$ & $\begin{array}{l}\text { Number of deaths: } \\
\text { Enoximone: } 27 \\
\text { Placebo: } 18, p<0.05 \\
\text { Sudden deaths: } \\
\text { Enoximone: } 11 \\
\text { Placebo: } 5 \\
\text { Progressive HF death: } \\
\text { Enoximone: } 12 \\
\text { Placebo: } 11 \\
\text { The trial was ended } \\
\text { early because of an } \\
\text { excess mortality in the } \\
\text { patients } \\
\text { treated with enoximone }\end{array}$ & Improved quality of life \\
\hline $\begin{array}{l}\text { Uretsky et al., } 199051 \\
\text { Enoximone trial } \\
\text { Double-blind, } \\
\text { randomized, placebo- } \\
\text { controlled } \\
\text { Enoximone vs placebo }\end{array}$ & 102 & 4 months & $\begin{array}{l}\text { Enoximone, } \\
\text { oral }\end{array}$ & $\begin{array}{l}\text { Not } \\
\text { reported }\end{array}$ & $\begin{array}{l}\text { Mortality: } \\
\text { Enoximone: } 5 \text { patients } \\
\text { Placebo: } 0 \text { patients, } \\
\text { p<0.05 } \\
\text { Two deaths were } \\
\text { sudden, two were from } \\
\text { progressive HF, and one } \\
\text { was from acute } \\
\text { myocardial infarction. }\end{array}$ & $\begin{array}{l}\text { No differences in } \\
\text { symptoms or exercise } \\
\text { duration at the end of } 4 \\
\text { months. }\end{array}$ \\
\hline
\end{tabular}




\begin{tabular}{|c|c|c|c|c|c|c|}
\hline $\begin{array}{l}\text { Hampton et al., } 1997^{54} \\
\text { Randomized, placebo- } \\
\text { controlled } \\
\text { Ibopamine vs placebo }\end{array}$ & 1906 & $\begin{array}{l}\text { About one } \\
\text { year }\end{array}$ & $\begin{array}{l}\text { Ibopamine, } \\
\text { oral }\end{array}$ & $\begin{array}{l}\text { Not } \\
\text { reported }\end{array}$ & $\begin{array}{l}\text { Mortality: } \\
\text { Ibopamine: } 232(25 \%) \\
\text { Placebo:193 (20\%) } \\
\text { Relative risk } 1.26 \text { [95\% } \\
\text { Cl 1.04-1.53], p = 0.017. } \\
\text { The trial was stopped } \\
\text { early, because of an } \\
\text { excess of deaths in the } \\
\text { ibopamine group }\end{array}$ & \\
\hline $\begin{array}{l}\text { Packer et al., } 1991 \\
55 \\
\text { Prospective } \\
\text { Randomized Milrinone } \\
\text { Survival Evaluation } \\
\text { (PROMISE) trial } \\
\text { Double blind, } \\
\text { randomized } \\
\text { Oral milrinone vs } \\
\text { placebo }\end{array}$ & 1088 & 6 months & $\begin{array}{l}\text { Oral } \\
\text { milrinone }\end{array}$ & $\begin{array}{l}\text { Not } \\
\text { reported }\end{array}$ & $\begin{array}{l}\text { Mortality from all } \\
\text { causes: } \\
\text { Milrinone: } 30 \% \\
\text { Placebo: } 24 \% \\
\text { A } 28 \% \text { increase in all } \\
\text { cause mortality, p = } \\
0.038 \text {, and a } 34 \% \\
\text { increase in } \\
\text { cardiovascular mortality, } \\
\text { p = 0.016). The trial } \\
\text { stopped prematurely } \\
\text { because of survival } \\
\text { compromise on } \\
\text { milrinone. }\end{array}$ & $\begin{array}{l}\text { Hospitalizations: } \\
\text { Milrinone } 44 \% \\
\text { Placebo } 39 \%, p=0.041\end{array}$ \\
\hline $\begin{array}{l}\text { The Xamoterol in } \\
\text { Severe Heart Failure } \\
\text { Study, } 1990{ }^{74} \text {. } \\
\text { Randomized, double- } \\
\text { blind, placebo-controlled } \\
\text { Randomization: } \\
\text { xamoterol vs placebo }\end{array}$ & 516 & 13 weeks & $\begin{array}{l}\text { Xamoterol, } \\
\text { oral (beta } \\
\text { receptor } \\
\text { agonist) }\end{array}$ & $\begin{array}{l}\text { Not } \\
\text { reported }\end{array}$ & $\begin{array}{l}\text { Mortality: } \\
\text { Xamoterol } 9.1 \% \\
\text { Placebo: } 3.7 \%, p=0.02\end{array}$ & \\
\hline
\end{tabular}


Table 4. Randomized control trials of inotropes in heart failure: neutral outcomes of inotropes

\begin{tabular}{|c|c|c|c|c|c|c|}
\hline Source, design & $\mathrm{N}$ & Follow-up & Inotrope & $\begin{array}{l}\text { Cardiac } \\
\text { index at } \\
\text { baseline }\end{array}$ & Mortality & $\begin{array}{l}\text { Other Outcomes in the } \\
\text { Inotrope group versus } \\
\text { Placebo }\end{array}$ \\
\hline $\begin{array}{l}\text { Cuffe et al., } 2002^{58} \\
\text { Outcomes of a } \\
\text { Prospective Trial of } \\
\text { Intravenous Milrinone for } \\
\text { Exacerbations } \\
\text { (OPTIME-HF) trial: } \\
\text { randomized, double- } \\
\text { blind, placebo- } \\
\text { controlled. } \\
\text { Milrinone vs placebo }\end{array}$ & 951 & 60 days & IV milrinone & $\begin{array}{l}\text { Not } \\
\text { reported }\end{array}$ & $\begin{array}{l}\text { In-hospital mortality } \\
\text { Milrinone: } 3.8 \% \\
\text { Placebo: } 2.3 \% \\
\text { 60-day mortality } \\
\text { Milrinone: } 10.3 \% \\
\text { Placebo: } 8.9 \% \\
\text { No difference }\end{array}$ & $\begin{array}{l}\text { Composite incidence of } \\
\text { death or readmission: no } \\
\text { difference } \\
\text { Milrinone: } 35 \% \\
\text { Placebo: } 35.3 \% \\
\text { The median number of } \\
\text { days hospitalized for } \\
\text { cardiovascular causes } \\
\text { within } 60 \text { days after } \\
\text { randomization: } \\
\text { No difference }\end{array}$ \\
\hline $\begin{array}{l}\text { Metra et al., } 200960 \\
\text { The Studies of Oral } \\
\text { Enoximone Therapy in } \\
\text { Advanced HF } \\
\text { (ESSENTIAL), two } \\
\text { identical, randomized, } \\
\text { double-blind, placebo- } \\
\text { controlled trials differed } \\
\text { only by location }\end{array}$ & 1854 & 17 months & $\begin{array}{l}\text { Enoximone, } \\
\text { oral }\end{array}$ & $\begin{array}{l}\text { Not } \\
\text { reported }\end{array}$ & $\begin{array}{l}\text { All-cause mortality: no } \\
\text { difference }\end{array}$ & $\begin{array}{l}\text { The } 6 \text { minute walk distance } \\
\text { increased with enoximone, } \\
\text { compared with placebo, in } \\
\text { ESSENTIAL-I ( } p=0.025 \text {, } \\
\text { not reaching, however, the } \\
\text { pre-specified criterion for } \\
\text { statistical significance of } p< \\
0.020\end{array}$ \\
\hline $\begin{array}{l}\text { Colucci et al., } 1993^{62} \\
\text { Two randomized } \\
\text { placebo controlled trials: } \\
\text { milrinone vs placebo }\end{array}$ & 140 & $\begin{array}{l}3-6 \\
\text { months }\end{array}$ & $\begin{array}{l}\text { Milrinone, } \\
\text { oral }\end{array}$ & $\begin{array}{l}\text { Not } \\
\text { reported }\end{array}$ & $\begin{array}{l}\text { No mortality difference. } \\
\text { Trials terminated } \\
\text { prematurely because of } \\
\text { the release of the } \\
\text { unfavorable results of } \\
\text { the other trial }\end{array}$ & $\begin{array}{l}\text { Improved exercise capacity } \\
\text { on milrinone }\end{array}$ \\
\hline $\begin{array}{l}\text { Dibianco et al., } 1984^{75} \\
\text { Randomized double- } \\
\text { blind withdrawal study } \\
\text { Patients who responded } \\
\text { to amrinone in the first } \\
\text { phase of the trial, were } \\
\text { randomized to continue } \\
\text { amrinone or to change } \\
\text { to placebo }\end{array}$ & 52 & 3 months & & $\begin{array}{l}\text { Not } \\
\text { reported }\end{array}$ & & $\begin{array}{l}\text { No difference in cardiac } \\
\text { performance or in } \\
\text { rehospitalizations or } \\
\text { functional status }\end{array}$ \\
\hline
\end{tabular}




\begin{tabular}{|c|c|c|c|c|c|c|}
\hline $\begin{array}{l}\text { Elis et al., } 199863 \\
\text { Randomized, double } \\
\text { blind, placebo controlled } \\
\text { Dobutamine vs placebo } \\
\text { over a } 24 \text {-hour period } \\
\text { every } 2 \text { to } 3 \text { weeks. }\end{array}$ & 19 & 6 months & $\begin{array}{l}\text { Dobutamine } \\
\text { IV, } \\
\text { intermittent }\end{array}$ & $\begin{array}{l}\text { Not } \\
\text { reported }\end{array}$ & $\begin{array}{l}\text { The median survival } \\
\text { Dobutamine: } 4.6 \text { months } \\
\text { Placebo } 8 \text { months } \\
\text { No difference }\end{array}$ & $\begin{array}{l}\text { No difference between the } \\
\text { number of admissions for } \\
\text { HF }\end{array}$ \\
\hline $\begin{array}{l}\text { Erlemeier et al., } 1992{ }^{64} \\
\text { Dobutamine vs placebo }\end{array}$ & 20 & 4 weeks & $\begin{array}{l}\text { Dobutamine, } \\
\text { IV } \\
\text { intermittent }\end{array}$ & $\begin{array}{l}\text { Not } \\
\text { reported }\end{array}$ & No mortality difference & $\begin{array}{l}\text { Dobutamine: exercise } \\
\text { duration increase, body } \\
\text { weight decreased } \\
\text { Placebo: no change }\end{array}$ \\
\hline $\begin{array}{l}\text { Oliva et al., } 199966 \\
\text { DICE } \\
\text { (Dobutaminanell'Insuffici } \\
\text { enza Cardiaca) trial: } \\
\text { Dobutamine vs standard } \\
\text { treatment }\end{array}$ & 38 & 6 months & $\begin{array}{l}\text { IV } \\
\text { dobutamine, } \\
\text { intermittent }\end{array}$ & $\begin{array}{l}1.89+/- \\
0.1 \\
\mathrm{~L} / \mathrm{min} / \mathrm{m}( \\
2)\end{array}$ & $\begin{array}{l}\text { Dobutamine: } 5 \text { deaths, } 2 \\
\text { heart transplants } \\
\text { Standard treatment: } 3 \\
\text { deaths. } \\
\text { No difference }\end{array}$ & $\begin{array}{l}\text { Hospitalizations for all } \\
\text { causes: no difference } \\
\text { Dobutamine: } 11 \text { ( } 7 \text { for HF) } \\
\text { Standard treatment: } 17 \text { (11 } \\
\text { for HF) } \\
\text { No difference in NYHA } \\
\text { class and in 6-minute } \\
\text { walking test. }\end{array}$ \\
\hline $\begin{array}{l}\text { Massie et al., } 1985^{65} \\
\text { Double-blind, placebo- } \\
\text { controlled } \\
\text { Amrinone vs placebo }\end{array}$ & 99 & 12 weeks & $\begin{array}{l}\text { Amrinone, } \\
\text { oral }\end{array}$ & $\begin{array}{l}\text { Not } \\
\text { reported }\end{array}$ & No mortality difference & $\begin{array}{l}\text { Exercise tolerance: no } \\
\text { difference }\end{array}$ \\
\hline $\begin{array}{l}\text { Narahara, } 1991^{67} \\
\text { The Western Enoximone } \\
\text { Study } \\
\text { Randomized, placebo } \\
\text { controlled } \\
\text { Enoximone vs placebo }\end{array}$ & 164 & 12 weeks & $\begin{array}{l}\text { Enoximone, } \\
\text { oral }\end{array}$ & $\begin{array}{l}\text { Not } \\
\text { reported }\end{array}$ & No mortality difference & $\begin{array}{l}\text { Enoximone: greater } \\
\text { increases in exercise time } \\
\text { than placebo treatment at } \\
\text { weeks } 4 \text { and } 8 \text { but not } \\
\text { after } 12 \text { weeks. }\end{array}$ \\
\hline $\begin{array}{l}\text { Van Veldhuisen et al., } \\
199368 \\
\text { The Dutch Ibopamine } \\
\text { Multicenter Trial } \\
\text { Double-blind placebo- } \\
\text { controlled, randomized } \\
\text { lbopamine vs digoxin vs } \\
\text { placebo }\end{array}$ & 161 & 6 months & $\begin{array}{l}\text { Ibopamine, } \\
\text { oral }\end{array}$ & $\begin{array}{l}\text { Not } \\
\text { reported }\end{array}$ & No mortality difference & \\
\hline
\end{tabular}


Table 5. Randomized control trials of inotropes in heart failure: good outcomes of inotropes

\begin{tabular}{|c|c|c|c|c|c|c|}
\hline Source, design & $\mathrm{N}$ & Follow-up & Inotrope & $\begin{array}{l}\text { Cardiac } \\
\text { index at } \\
\text { baseline }\end{array}$ & Mortality & $\begin{array}{l}\text { Other Outcomes in the } \\
\text { Inotrope group versus } \\
\text { Placebo }\end{array}$ \\
\hline $\begin{array}{l}\text { Dubourg et al., } 199069 \\
\text { A double-blind, } \\
\text { randomized trial } \\
\text { Enoximone vs. placebo }\end{array}$ & 30 & 31 days & $\begin{array}{l}\text { Enoximone, } \\
\text { oral }\end{array}$ & $\begin{array}{l}2.17+/- \\
0.7 \\
\mathrm{~L} / \mathrm{min} / \mathrm{m} 2\end{array}$ & $\begin{array}{l}\text { Mortality } \\
\text { Enoximone: } 1 \\
\text { Placebo: } 3\end{array}$ & $\begin{array}{l}\text { Symptoms improvement on } \\
\text { enoximone }\end{array}$ \\
\hline $\begin{array}{l}\text { Feldman et al, } 2007^{61} \text {. } \\
\text { EMOTE trial } \\
\text { (Enoximone in } \\
\text { Intravenous Inotrope- } \\
\text { Dependent Subjects } \\
\text { Study } \\
\text { Enoximone or placebo. } \\
\text { Enoximone was used to } \\
\text { wean patients from IV } \\
\text { inotropes }\end{array}$ & 201 & 6 months & $\begin{array}{l}\text { Oral } \\
\text { enoximone }\end{array}$ & $\begin{array}{l}\text { Not } \\
\text { reported }\end{array}$ & 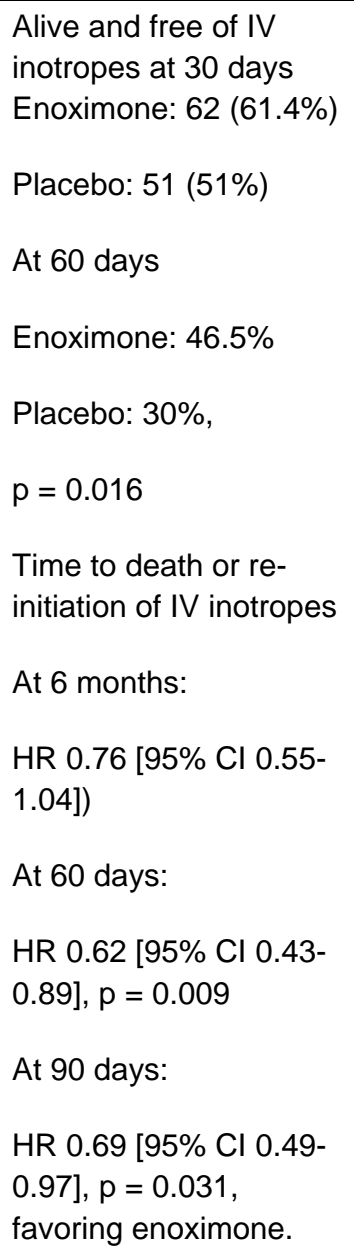 & \\
\hline $\begin{array}{l}\text { Feldman et al., } 1993^{70} \\
\text { Vesnarinone Study } \\
\text { Randomized, double- } \\
\text { blind, placebo-controlled } \\
\text { Vesnarinone vs } \\
\text { placebo }\end{array}$ & 477 & 6 months & $\begin{array}{l}\text { Vesnarinone, } \\
\text { oral }\end{array}$ & $\begin{array}{l}\text { Not } \\
\text { reported }\end{array}$ & $\begin{array}{l}\text { Mortality plus worsening } \\
\text { HF: } \\
\text { Vesnarinone: } 26 \\
\text { Placebo: } 50, p=0.003 \\
\text { A } 62 \% \text { reduction (95\% } \\
\mathrm{Cl}, 28 \text { - } 80 \% \text { ) in the risk } \\
\text { of dying from any cause }\end{array}$ & $\begin{array}{l}\text { Vesnarinone: quality of life } \\
\text { improved to a greater } \\
\text { extent than in the placebo } \\
\text { group over } 12 \text { weeks ( } \mathrm{P}= \\
0.008)\end{array}$ \\
\hline
\end{tabular}




\begin{tabular}{|c|c|c|c|c|c|c|}
\hline & & & & & $\begin{array}{l}\text { among the patients } \\
\text { receiving vesnarinone }\end{array}$ & \\
\hline $\begin{array}{l}\text { Nanas et al., } 200457 \\
\text { Randomized, double- } \\
\text { blind, placebo-controlled } \\
\text { clinical trial. } \\
\text { Dobutamine vs placebo }\end{array}$ & 30 & 6 months & $\begin{array}{l}\text { Dobutamine, } \\
\text { IV } \\
\text { Intermittent, } \\
\text { plus } \\
\text { amiodarone }\end{array}$ & $\begin{array}{l}2.3 \pm 0.7 \\
\mathrm{~L} / \mathrm{min} / \mathrm{m}( \\
2)\end{array}$ & $\begin{array}{l}\text { Survival } \\
\text { Dobutamine plus } \\
\text { amiodarone vs placebo } \\
\text { plus amiodarone } \\
\text { HR=0.403; } 95 \% \mathrm{Cl}= \\
0.164 \text {-0.992; } \mathrm{p}=0.048 \\
\text { 1-year survival estimate } \\
\text { Dobutamine plus } \\
\text { amiodarone: } 69 \% \\
\text { Placebo plus } \\
\text { amiodarone: } 28 \% \text {, } \\
\text { p<0.05 } \\
\text { 2-year survival estimate } \\
\text { Dobutamine plus } \\
\text { amiodarone: } 44 \% \\
\text { Placebo plus } \\
\text { amiodarone: } 21 \% \text {, } \\
\text { p<0.05 }\end{array}$ & \\
\hline $\begin{array}{l}\text { Likoff et al., } 1984{ }^{71} \\
\text { Randomized, double } \\
\text { blind, placebo controlled } \\
\text { After being stabilized on } \\
\text { amrinone, patients were } \\
\text { randomized into } \\
\text { continuation on } \\
\text { amrinone or withdrawal } \\
\text { of amrinone }\end{array}$ & 9 & $\begin{array}{l}\text { Two } 13 \\
\text { week } \\
\text { stages }\end{array}$ & Amrinone, IV & $\begin{array}{l}1.9+/- \\
0.2 \mathrm{~L} / \mathrm{min} / \\
\mathrm{m} 2\end{array}$ & & $\begin{array}{l}\text { Placebo: } 7 \text { patients had a } \\
\text { significant deterioration of } \\
\text { symptoms or exercise } \\
\text { tolerance, or both. After } 4 \\
\text { weeks of readministration } \\
\text { of amrinone, clinical status } \\
\text { improved }\end{array}$ \\
\hline $\begin{array}{l}\text { Khalife et al., } 19877^{76} \\
\text { Double-blind, } \\
\text { randomized, placebo } \\
\text { controlled } \\
\text { Randomization: after the } \\
\text { first phase when IV } \\
\text { enoximone was given to } \\
\text { all patients, they were } \\
\text { randomized into oral } \\
\text { Enoximone or placebo. }\end{array}$ & 17 & 12 weeks & $\begin{array}{l}\text { Enoximone, } \\
\text { IV and oral, } \\
\text { in a 2-part } \\
\text { study }\end{array}$ & $\begin{array}{l}3.42+/- \\
0.72 \\
\text { L/min/m2 } \\
\text { (after } \\
\text { Enoximo } \\
\text { ne IV) }\end{array}$ & & $\begin{array}{l}\text { Enoximone: left ventricular } \\
\text { ejection fraction improved } \\
\text { from } 30.1+/-6.8 \% \text { to } 33.9 \\
+/-9.9 \% \\
\text { Placebo: unchanged }\end{array}$ \\
\hline
\end{tabular}




\section{References}

1. Follath F, Yilmaz MB, Delgado JF, Parissis JT, Porcher R, Gayat E, Burrows N, McLean A, Vilas-Boas F, Mebazaa A. Clinical presentation, management and outcomes in the Acute Heart Failure Global Survey of Standard Treatment (ALARM-HF). Intensive care medicine 2011;37:619-626.

2. Rose EA, Gelijns AC, Moskowitz AJ, Heitjan DF, Stevenson LW, Dembitsky W, Long JW, Ascheim DD, Tierney AR, Levitan RG, Watson JT, Meier P, Ronan NS, Shapiro PA, Lazar RM, Miller LW, Gupta L, Frazier OH, Desvigne-Nickens P, Oz MC, Poirier VL. Long-term use of a left ventricular assist device for end-stage heart failure. The New England journal of medicine 2001;345:1435-1443.

3. Yancy CW, Jessup M, Bozkurt B, Masoudi FA, Butler J, McBride PE, Casey DE, Jr., McMurray JJ, Drazner MH, Mitchell JE, Fonarow GC, Peterson PN, Geraci SA, Horwich T, Januzzi JL, Johnson MR, Kasper EK, Levy WC, Riegel B, Sam F, Stevenson LW, Tang WH, Tsai EJ, Wilkoff BL. 2013 ACCF/AHA Guideline for the Management of Heart Failure: A Report of the American College of Cardiology Foundation/American Heart Association Task Force on Practice Guidelines. Journal of the American College of Cardiology 2013.

4. Lindenfeld J, Albert NM, Boehmer JP, Collins SP, Ezekowitz JA, Givertz MM, Katz SD, Klapholz M, Moser DK, Rogers JG, Starling RC, Stevenson WG, Tang WH, Teerlink JR, Walsh MN. HFSA 2010 Comprehensive Heart Failure Practice Guideline. $J$ Card Fail 2010;16:e1-194.

5. McMurray JJ, Adamopoulos S, Anker SD, Auricchio A, Bohm M, Dickstein K, Falk V, Filippatos G, Fonseca C, Gomez-Sanchez MA, Jaarsma T, Kober L, Lip GY, Maggioni AP, Parkhomenko A, Pieske BM, Popescu BA, Ronnevik PK, Rutten FH, Schwitter J, Seferovic P, Stepinska J, Trindade PT, Voors AA, Zannad F, Zeiher A. ESC Guidelines for the diagnosis and treatment of acute and chronic heart failure 2012: The Task Force for the Diagnosis and Treatment of Acute and Chronic Heart Failure 2012 of the European Society of Cardiology. Developed in collaboration with the Heart Failure Association (HFA) of the ESC. European heart journal 2012;33:1787-1847.

6. Jessup M, Banner N, Brozena S, Campana C, Costard-Jackle A, Dengler T, Hunt S, Metra M, Rahmel A, Renlund D, Ross H, Warner Stevenson L. Optimal pharmacologic and non-pharmacologic management of cardiac transplant candidates: approaches to be considered prior to transplant evaluation: International Society for Heart and Lung Transplantation guidelines for the care of cardiac transplant candidates--2006. The Journal of heart and lung transplantation : the official publication of the International Society for Heart Transplantation 2006;25:1003-1023.

7. Feldman D, Pamboukian SV, Teuteberg JJ, Birks E, Lietz K, Moore SA, Morgan JA, Arabia F, Bauman ME, Buchholz HW, Deng M, Dickstein ML, El-Banayosy A, Elliot T, Goldstein DJ, Grady KL, Jones K, Hryniewicz K, John R, Kaan A, Kusne S, Loebe M, Massicotte MP, Moazami N, Mohacsi P, Mooney M, Nelson T, Pagani F, Perry W, Potapov EV, Eduardo Rame J, Russell SD, Sorensen EN, Sun B, Strueber M, Mangi AA, Petty MG, Rogers J. The 2013 International Society for Heart and Lung Transplantation 
Guidelines for mechanical circulatory support: executive summary. The Journal of heart and lung transplantation : the official publication of the International Society for Heart Transplantation 2013;32:157-187.

8. Costanzo MR, Dipchand A, Starling R, Anderson A, Chan M, Desai S, Fedson S, Fisher P, Gonzales-Stawinski G, Martinelli L, McGiffin D, Smith J, Taylor D, Meiser B, Webber S, Baran D, Carboni M, Dengler T, Feldman D, Frigerio M, Kfoury A, Kim D, Kobashigawa J, Shullo M, Stehlik J, Teuteberg J, Uber P, Zuckermann A, Hunt S, Burch M, Bhat G, Canter C, Chinnock R, Crespo-Leiro M, Delgado R, Dobbels F, Grady K, Kao W, Lamour J, Parry G, Patel J, Pini D, Towbin J, Wolfel G, Delgado D, Eisen H, Goldberg L, Hosenpud J, Johnson M, Keogh A, Lewis C, O'Connell J, Rogers J, Ross H, Russell S, Vanhaecke J. The International Society of Heart and Lung Transplantation Guidelines for the care of heart transplant recipients. The Journal of heart and lung transplantation : the official publication of the International Society for Heart Transplantation 2010;29:914-956.

9. Sonnenblick EH, Frishman WH, LeJemtel TH. Dobutamine: a new synthetic cardioactive sympathetic amine. The New England journal of medicine 1979;300:17-22.

10. Baim DS, McDowell AV, Cherniles J, Monrad ES, Parker JA, Edelson J, Braunwald E, Grossman W. Evaluation of a new bipyridine inotropic agent--milrinone--in patients with severe congestive heart failure. The New England journal of medicine 1983;309:748-756.

11. Guglin M, Kaufman M. Inotropes do not increase mortality in advanced heart failure. International journal of general medicine 2014;7:237-251.

12. Anderson JL. Hemodynamic and clinical benefits with intravenous milrinone in severe chronic heart failure: results of a multicenter study in the United States. American heart journal 1991;121:1956-1964.

13. Klocke RK, Mager G, Kux A, Hopp HW, Hilger HH. Effects of a twenty-four-hour milrinone infusion in patients with severe heart failure and cardiogenic shock as a function of the hemodynamic initial condition. American heart journal 1991;121:19651973.

14. Biddle TL, Benotti JR, Creager MA, Faxon DP, Firth BG, Fitzpatrick PG, Konstam MA, Krebs C, Walton L, Kershner RP, et al. Comparison of intravenous milrinone and dobutamine for congestive heart failure secondary to either ischemic or dilated cardiomyopathy. The American journal of cardiology 1987;59:1345-1350.

15. Monrad ES, Baim DS, Smith HS, Lanoue AS. Milrinone, dobutamine, and nitroprusside: comparative effects on hemodynamics and myocardial energetics in patients with severe congestive heart failure. Circulation 1986;73:III168-174.

16. Stevenson LW. Clinical use of inotropic therapy for heart failure: looking backward or forward? Part I: inotropic infusions during hospitalization. Circulation 2003;108:367372. 
17. Colucci WS, Wright RF, Jaski BE, Fifer MA, Braunwald E. Milrinone and dobutamine in severe heart failure: differing hemodynamic effects and individual patient responsiveness. Circulation 1986;73:III175-183.

18. Lowes BD, Tsvetkova T, Eichhorn EJ, Gilbert EM, Bristow MR. Milrinone versus dobutamine in heart failure subjects treated chronically with carvedilol. International journal of cardiology 2001;81:141-149.

19. David S, Zaks JM. Arrhythmias associated with intermittent outpatient dobutamine infusion. Angiology 1986;37:86-91.

20. Burger AJ, Horton DP, LeJemtel T, Ghali JK, Torre G, Dennish G, Koren M, Dinerman J, Silver M, Cheng ML, Elkayam U. Effect of nesiritide (B-type natriuretic peptide) and dobutamine on ventricular arrhythmias in the treatment of patients with acutely decompensated congestive heart failure: the PRECEDENT study. American heart journal 2002;144:1102-1108.

21. Aranda JM, Jr., Schofield RS, Pauly DF, Cleeton TS, Walker TC, Monroe VS, Jr., Leach D, Lopez LM, Hill JA. Comparison of dobutamine versus milrinone therapy in hospitalized patients awaiting cardiac transplantation: a prospective, randomized trial. American heart journal 2003;145:324-329.

22. Toma M, Starling RC. Inotropic therapy for end-stage heart failure patients. Curr Treat Options Cardiovasc Med 2010;12:409-419.

23. Stevenson LW, Massie BM, Francis GS. Optimizing therapy for complex or refractory heart failure: a management algorithm. American heart journal 1998;135:S293-309.

24. Nohria A, Tsang SW, Fang JC, Lewis EF, Jarcho JA, Mudge GH, Stevenson LW. Clinical assessment identifies hemodynamic profiles that predict outcomes in patients admitted with heart failure. Journal of the American College of Cardiology 2003;41:1797-1804.

25. Leier CV, Webel J, Bush CA. The cardiovascular effects of the continuous infusion of dobutamine in patients with severe cardiac failure. Circulation 1977;56:468-472.

26. Stevenson LW. Clinical use of inotropic therapy for heart failure: looking backward or forward? Part II: chronic inotropic therapy. Circulation 2003;108:492-497.

27. Stevenson LW, Pagani FD, Young JB, Jessup M, Miller L, Kormos RL, Naftel DC, Ulisney K, Desvigne-Nickens P, Kirklin JK. INTERMACS profiles of advanced heart failure: the current picture. The Journal of heart and lung transplantation : the official publication of the International Society for Heart Transplantation 2009;28:535-541.

28. Hershberger RE, Nauman D, Walker TL, Dutton D, Burgess D. Care processes and clinical outcomes of continuous outpatient support with inotropes (COSI) in patients with refractory endstage heart failure. J Card Fail 2003;9:180-187. 
29. Unverferth DV, Magorien RD, Altschuld R, Kolibash AJ, Lewis RP, Leier CV. The hemodynamic and metabolic advantages gained by a three-day infusion of dobutamine in patients with congestive cardiomyopathy. American heart journal 1983;106:29-34.

30. Cusick DA, Pfeifer PB, Quigg RJ. Effects of intravenous milrinone followed by titration of high-dose oral vasodilator therapy on clinical outcome and rehospitalization rates in patients with severe heart failure. The American journal of cardiology 1998;82:1060-1065.

31. Capomolla S, Febo O, Opasich C, Guazzotti G, Caporotondi A, La Rovere MT, Gnemmi M, Mortara A, Vona M, Pinna GD, Maestri R, Cobelli F. Chronic infusion of dobutamine and nitroprusside in patients with end-stage heart failure awaiting heart transplantation: safety and clinical outcome. European journal of heart failure 2001;3:601-610.

32. Silver MA, Horton DP, Ghali JK, Elkayam U. Effect of nesiritide versus dobutamine on short-term outcomes in the treatment of patients with acutely decompensated heart failure. Journal of the American College of Cardiology 2002;39:798-803.

33. Hauptman PJ, Mikolajczak P, George A, Mohr CJ, Hoover R, Swindle J, Schnitzler MA. Chronic inotropic therapy in end-stage heart failure. American heart journal 2006;152:1096 e1091-1098.

34. Harjai KJ, Mehra MR, Ventura HO, Lapeyre YM, Murgo JP, Stapleton DD, Smart FW. Home inotropic therapy in advanced heart failure: cost analysis and clinical outcomes. Chest 1997;112:1298-1303.

35. Brozena SC, Twomey C, Goldberg LR, Desai SS, Drachman B, Kao A, Popjes E, Zimmer R, Jessup M. A prospective study of continuous intravenous milrinone therapy for status IB patients awaiting heart transplant at home. The Journal of heart and lung transplantation : the official publication of the International Society for Heart Transplantation 2004;23:1082-1086.

36. Canver CC, Chanda J. Milrinone for long-term pharmacologic support of the status 1 heart transplant candidates. The Annals of thoracic surgery 2000;69:1823-1826.

37. Upadya S, Lee FA, Saldarriaga C, Verma S, Sedrakyan A, Nystrom K, Katz SD. Home continuous positive inotropic infusion as a bridge to cardiac transplantation in patients with end-stage heart failure. The Journal of heart and lung transplantation : the official publication of the International Society for Heart Transplantation 2004;23:466472.

38. Sindone AP, Keogh AM, Macdonald PS, McCosker CJ, Kaan AF. Continuous home ambulatory intravenous inotropic drug therapy in severe heart failure: safety and cost efficacy. American heart journal 1997;134:889-900.

39. Miller LW, Merkle EJ, Herrmann V. Outpatient dobutamine for end-stage congestive heart failure. Critical care medicine 1990;18:S30-33. 
40. Elkayam U, Tasissa G, Binanay C, Stevenson LW, Gheorghiade M, Warnica JW, Young JB, Rayburn BK, Rogers JG, DeMarco T, Leier CV. Use and impact of inotropes and vasodilator therapy in hospitalized patients with severe heart failure. American heart journal 2007;153:98-104.

41. Abraham WT, Adams KF, Fonarow GC, Costanzo MR, Berkowitz RL, LeJemtel TH, Cheng ML, Wynne J, Committee ASA, Investigators, Group AS. In-hospital mortality in patients with acute decompensated heart failure requiring intravenous vasoactive medications: an analysis from the Acute Decompensated Heart Failure National Registry (ADHERE). Journal of the American College of Cardiology 2005;46:57-64.

42. O'Connor CM, Gattis WA, Uretsky BF, Adams KF, Jr., McNulty SE, Grossman SH, McKenna WJ, Zannad F, Swedberg K, Gheorghiade M, Califf RM. Continuous intravenous dobutamine is associated with an increased risk of death in patients with advanced heart failure: insights from the Flolan International Randomized Survival Trial (FIRST). American heart journal 1999;138:78-86.

43. Rossinen J, Harjola VP, Siirila-Waris K, Lassus J, Melin J, Peuhkurinen K, Nieminen MS. The use of more than one inotrope in acute heart failure is associated with increased mortality: a multi-centre observational study. Acute cardiac care 2008;10:209-213.

44. Thackray S, Easthaugh J, Freemantle N, Cleland JG. The effectiveness and relative effectiveness of intravenous inotropic drugs acting through the adrenergic pathway in patients with heart failure-a meta-regression analysis. European journal of heart failure 2002;4:515-529.

45. Amsallem E, Kasparian C, Haddour G, Boissel JP, Nony P. Phosphodiesterase III inhibitors for heart failure. The Cochrane database of systematic reviews 2005:CD002230.

46. Gorodeski EZ, Chu EC, Reese JR, Shishehbor MH, Hsich E, Starling RC. Prognosis on chronic dobutamine or milrinone infusions for stage D heart failure. Circ Heart Fail 2009;2:320-324.

47. Mehra MR, Ventura HO, Kapoor C, Stapleton DD, Zimmerman D, Smart FW. Safety and clinical utility of long-term intravenous milrinone in advanced heart failure. The American journal of cardiology 1997;80:61-64.

48. Uretsky BF, Jessup M, Konstam MA, Dec GW, Leier CV, Benotti J, Murali S, Herrmann HC, Sandberg JA. Multicenter trial of oral enoximone in patients with moderate to moderately severe congestive heart failure. Lack of benefit compared with placebo. Enoximone Multicenter Trial Group. Circulation 1990;82:774-780.

49. Cowley AJ, Skene AM. Treatment of severe heart failure: quantity or quality of life? A trial of enoximone. Enoximone Investigators. British heart journal 1994;72:226-230.

50. Cohn JN, Goldstein SO, Greenberg BH, Lorell BH, Bourge RC, Jaski BE, Gottlieb SO, McGrew F, 3rd, DeMets DL, White BG. A dose-dependent increase in mortality with vesnarinone among patients with severe heart failure. Vesnarinone Trial Investigators. The New England journal of medicine 1998;339:1810-1816. 
51. Hampton JR, van Veldhuisen DJ, Kleber FX, Cowley AJ, Ardia A, Block P, Cortina A, Cserhalmi L, Follath F, Jensen G, Kayanakis J, Lie KI, Mancia G, Skene AM. Randomised study of effect of ibopamine on survival in patients with advanced severe heart failure. Second Prospective Randomised Study of Ibopamine on Mortality and Efficacy (PRIME II) Investigators. Lancet 1997;349:971-977.

52. Packer M, Carver JR, Rodeheffer RJ, Ivanhoe RJ, DiBianco R, Zeldis SM, Hendrix GH, Bommer WJ, Elkayam U, Kukin ML, et al. Effect of oral milrinone on mortality in severe chronic heart failure. The PROMISE Study Research Group. The New England journal of medicine 1991;325:1468-1475.

53. Drakos SG, Kanakakis JV, Nanas S, Bonios M, Kaldara E, Katsaros F, Pantsios C, Nanas JN. Intermittent inotropic infusions combined with prophylactic oral amiodarone for patients with decompensated end-stage heart failure. Journal of cardiovascular pharmacology 2009;53:157-161.

54. Nanas JN, Tsagalou EP, Kanakakis J, Nanas SN, Terrovitis JV, Moon T, AnastasiouNana MI. Long-term intermittent dobutamine infusion, combined with oral amiodarone for end-stage heart failure: a randomized double-blind study. Chest 2004;125:1198-1204. 55. Cuffe MS, Califf RM, Adams KF, Jr., Benza R, Bourge R, Colucci WS, Massie BM, O'Connor CM, Pina I, Quigg R, Silver MA, Gheorghiade M. Short-term intravenous milrinone for acute exacerbation of chronic heart failure: a randomized controlled trial. JAMA : the journal of the American Medical Association 2002;287:1541-1547.

56. Felker GM, Benza RL, Chandler AB, Leimberger JD, Cuffe MS, Califf RM, Gheorghiade M, O'Connor CM. Heart failure etiology and response to milrinone in decompensated heart failure: results from the OPTIME-CHF study. Journal of the American College of Cardiology 2003;41:997-1003.

57. Metra M, Eichhorn E, Abraham WT, Linseman J, Bohm M, Corbalan R, DeMets D, De Marco T, Elkayam U, Gerber M, Komajda M, Liu P, Mareev V, Perrone SV, PooleWilson P, Roecker E, Stewart J, Swedberg K, Tendera M, Wiens B, Bristow MR. Effects of low-dose oral enoximone administration on mortality, morbidity, and exercise capacity in patients with advanced heart failure: the randomized, double-blind, placebo-controlled, parallel group ESSENTIAL trials. European heart journal 2009;30:3015-3026.

58. Feldman AM, Oren RM, Abraham WT, Boehmer JP, Carson PE, Eichhorn E, Gilbert EM, Kao A, Leier CV, Lowes BD, Mathier MA, McGrew FA, Metra M, Zisman LS, Shakar SF, Krueger SK, Robertson AD, White BG, Gerber MJ, Wold GE, Bristow MR. Low-dose oral enoximone enhances the ability to wean patients with ultra-advanced heart failure from intravenous inotropic support: results of the oral enoximone in intravenous inotrope-dependent subjects trial. American heart journal 2007;154:861-869.

59. Colucci WS, Sonnenblick EH, Adams KF, Berk M, Brozena SC, Cowley AJ, Grabicki JM, Kubo SA, LeJemtel T, Littler WA, et al. Efficacy of phosphodiesterase inhibition with milrinone in combination with converting enzyme inhibitors in patients with heart failure. The Milrinone Multicenter Trials Investigators. Journal of the American College of Cardiology 1993;22:113A-118A. 
60. Elis A, Bental T, Kimchi O, Ravid M, Lishner M. Intermittent dobutamine treatment in patients with chronic refractory congestive heart failure: a randomized, double-blind, placebo-controlled study. Clinical pharmacology and therapeutics 1998;63:682-685.

61. Erlemeier HH, Kupper W, Bleifeld W. Intermittent infusion of dobutamine in the therapy of severe congestive heart failure--long-term effects and lack of tolerance. Cardiovascular drugs and therapy / sponsored by the International Society of Cardiovascular Pharmacotherapy 1992;6:391-398.

62. Massie B, Bourassa M, DiBianco R, Hess M, Konstam M, Likoff M, Packer M. Long-term oral administration of amrinone for congestive heart failure: lack of efficacy in a multicenter controlled trial. Circulation 1985;71:963-971.

63. Oliva F, Latini R, Politi A, Staszewsky L, Maggioni AP, Nicolis E, Mauri F. Intermittent 6-month low-dose dobutamine infusion in severe heart failure: DICE multicenter trial. American heart journal 1999;138:247-253.

64. Narahara KA. Oral enoximone therapy in chronic heart failure: a placebo-controlled randomized trial. The Western Enoximone Study Group. American heart journal 1991;121:1471-1479.

65. van Veldhuisen DJ, Man in 't Veld AJ, Dunselman PH, Lok DJ, Dohmen HJ, Poortermans JC, Withagen AJ, Pasteuning WH, Brouwer J, Lie KI. Double-blind placebo-controlled study of ibopamine and digoxin in patients with mild to moderate heart failure: results of the Dutch Ibopamine Multicenter Trial (DIMT). Journal of the American College of Cardiology 1993;22:1564-1573.

66. Dubourg O, Delorme G, Hardy A, Beauchet A, Tarral A, Bourdarias JP. Placebocontrolled trial of oral enoximone in end-stage congestive heart failure refractory to optimal treatment. International journal of cardiology 1990;28 Suppl 1:S33-42; discussion S43.

67. Feldman AM, Bristow MR, Parmley WW, Carson PE, Pepine CJ, Gilbert EM, Strobeck JE, Hendrix GH, Powers ER, Bain RP, et al. Effects of vesnarinone on morbidity and mortality in patients with heart failure. Vesnarinone Study Group. The New England journal of medicine 1993;329:149-155.

68. Likoff MJ, Weber KT, Andrews V, Janicki JS, Sutton MS, Wilson H, Rocci ML, Jr. Amrinone in the treatment of chronic cardiac failure. Journal of the American College of Cardiology 1984;3:1282-1290. 
The VAD Journal: The journal of mechanical assisted circulation and heart failure 